\title{
Groundwater's significance to changing hydrology, water chemistry, and biological communities of a floodplain ecosystem, Everglades, South Florida, USA
}

\author{
Judson W. Harvey • Paul V. McCormick
}

\begin{abstract}
The Everglades (Florida, USA) is one of the world's larger subtropical peatlands with biological communities adapted to waters low in total dissolved solids and nutrients. Detecting how the pre-drainage hydrological system has been altered is crucial to preserving its functional attributes. However, reliable tools for hindcasting historic conditions in the Everglades are limited. A recent synthesis demonstrates that the proportion of surface-water inflows has increased relative to precipitation, accounting for $33 \%$ of total inputs compared with $18 \%$ historically. The largest new source of water is canal drainage from areas of former wetlands converted to agriculture. Interactions between groundwater and surface water have also increased, due to increasing vertical hydraulic gradients resulting from topographic and water-level alterations on the otherwise extremely flat landscape. Environmental solute tracer data were used to determine groundwater's changing role, from a freshwater storage reservoir that sustained the Everglades ecosystem during dry periods to a reservoir of increasingly degraded water quality. Although some of this degradation is attributable to increased discharge of deep saline groundwater, other mineral sources such as fertilizer additives and peat oxidation have made a greater contri-
\end{abstract}

Received: 28 January 2008 / Accepted: 29 September 2008

Published online: 29 October 2008

(C) Springer-Verlag 2008

J. W. Harvey (

US Geological Survey,

12201 Sunrise Valley Drive, MS 430, Reston, VA 20192, USA

e-mail: jwharvey@usgs.gov

P. V. McCormick

Leetown Science Center,

US Geological Survey,

11700 Leetown Road, Kearneysville, WV 25430, USA

P. V. McCormick

Now at South Florida Water Management District,

3301 Gun Club Road, West Palm Beach, FL 33406, USA

e-mail: pmccormi@sfwmd.gov bution to water-quality changes that are altering mineralsensitive biological communities.

Keywords Coastal aquifers · Contamination . Groundwater/surface-water relations · Paleohydrology · USA · Wetlands · Everglades

\section{Introduction}

Large, low-gradient peatlands occur worldwide. Many of those, like the Everglades, are lotic peatlands with surface water flow occurring for much of the year through wetlands that are large enough to maintain low nutrient status and dominantly organic soils. Lotic peatlands dominated by emergent vegetation often exhibit a flowrelated patterning; these landscapes include boreal fens (Glaser et al. 1981), the Okavango Delta in Botswana (Ellery et al. 2003; Gumbricht et al. 2004), morichal wetlands in Columbia and Venezuela (San Jose et al. 2001), buritizal wetlands in the Brazilian Pantanal, the Zapata peninsula in southern Cuba, Costa Rica's lower Tempisque River basin, and some riparian wetlands on river floodplains. Groundwater's influence in the hydrology of these large lotic wetlands has been revealed in a few instances (Siegel and Glaser 1987; McCarthy 2006; Harvey et al. 2006), although a comprehensive understanding of the role of groundwater in structuring these ecosystems has only begun to emerge.

The Everglades is a very large subtropical coastal wetland within a larger watershed that extends $160 \mathrm{~km}$ from the Kissimmee River basin through Lake Okeechobee to Florida Bay in southeastern Florida (Fig. 1). The biological communities of the Everglades are adapted to low-mineral and low-nutrient conditions created by overland flow of fresh surface water across a vast vegetated floodplain with very low slope. During the early and mid-twentieth century, the Everglades was managed primarily to accomplish drainage and flood control. In 1910, construction began on canals for drainage and flood control that extended southeast from Lake Okeechobee to the Atlantic Ocean (Light and Dineen 1994). With the passage of time, came growing 
a
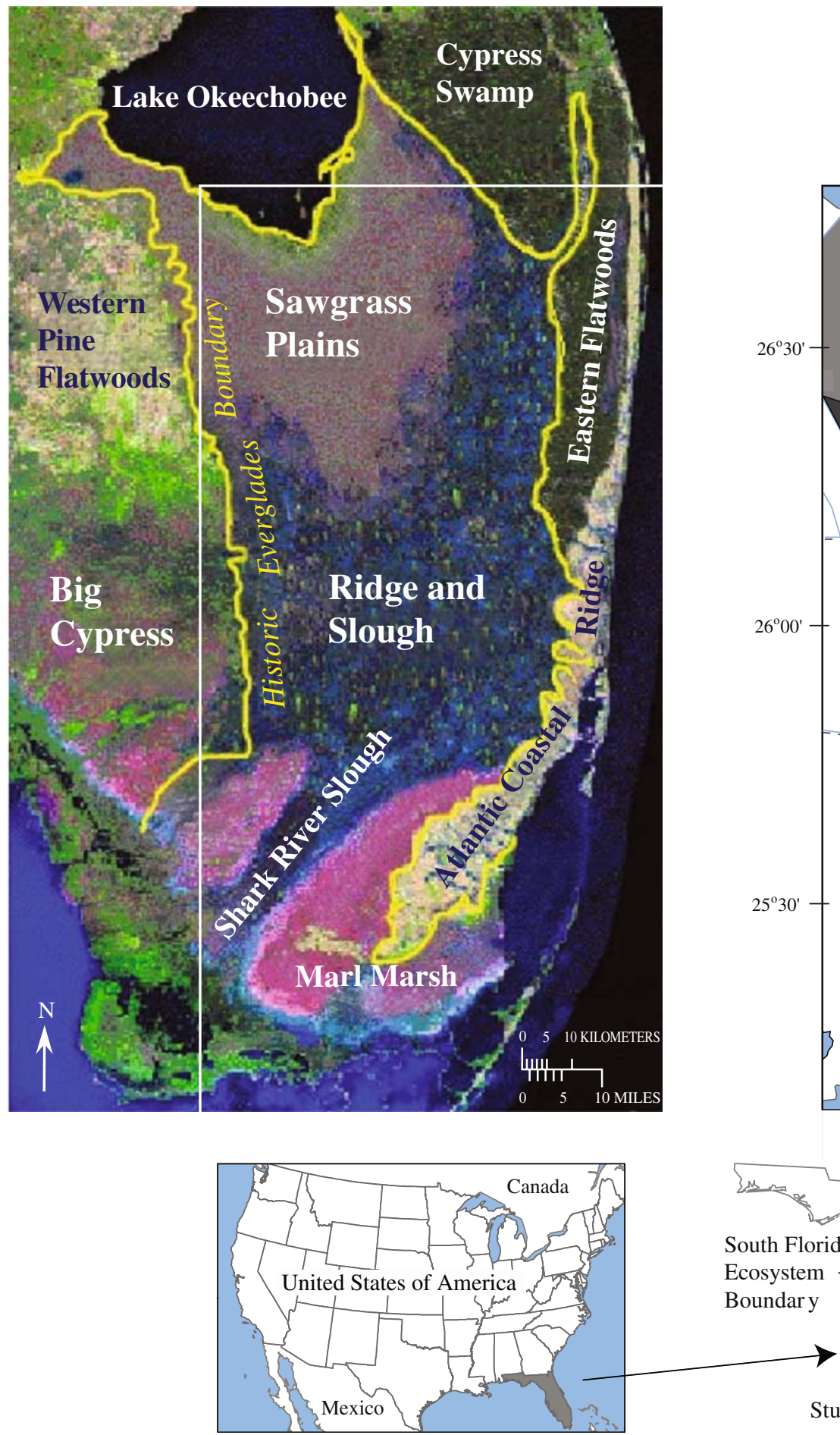

b

\section{Explanation}

Water Conservation Areas (WCAs)

Everglades Agricultural Area (EAA)

Stormwater Treatment Areas (STAs)

Major Canals

○ Major Water Control Structures
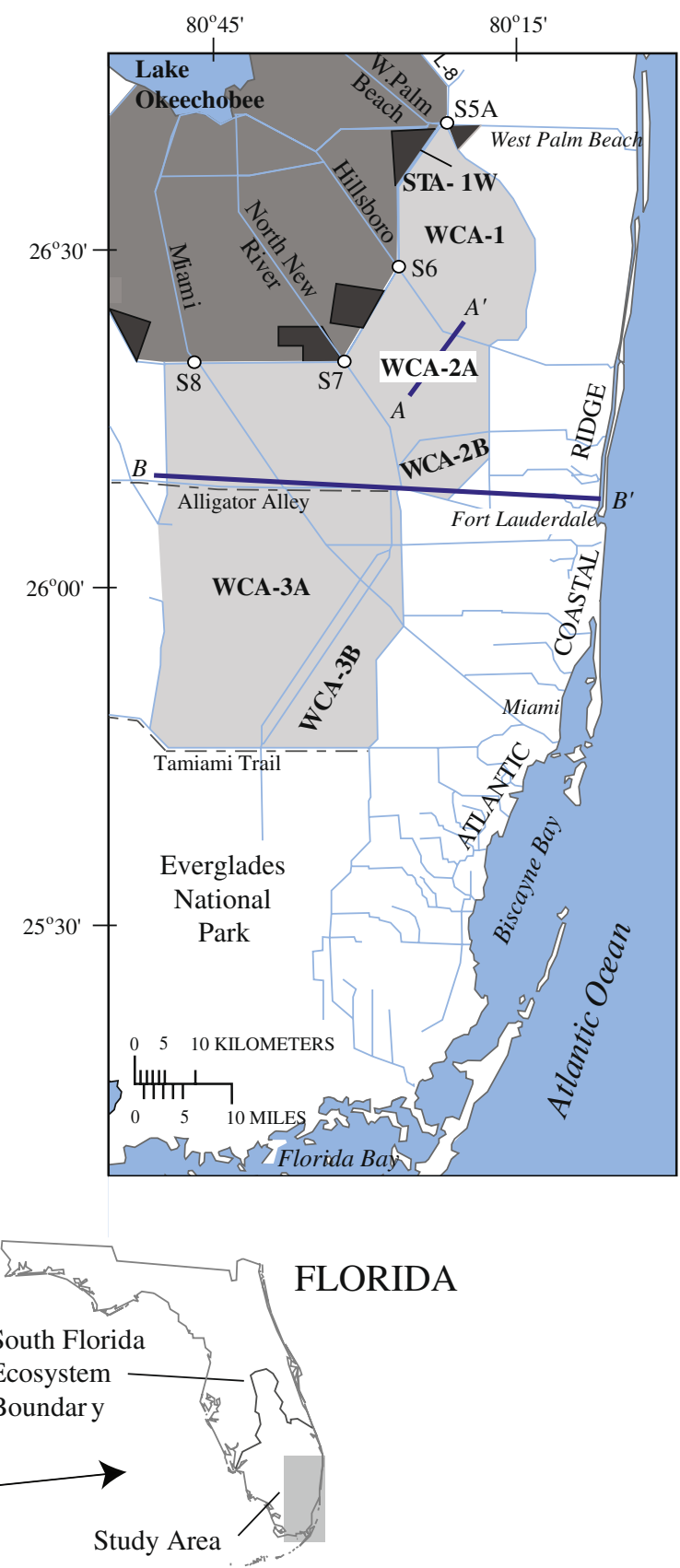

Fig. 1 a Reconstruction of pre-drainage Everglades boundaries and landscape patterns prior to 1900, compared with b present-day features of the managed Everglades. The pre-drainage reconstruction is by the Science Coordination Team (2003) who created the image using overlays on recent satellite coverage. For comparison with present-day conditions in the study area, the rectangular white outline in a matches b which outlines the large area converted to agriculture (EAA), the remaining central Everglades divided into sub-basins (WCAs), major canals and water control structures, two major highways crossing the Everglades (dashed lines), and Everglades National Park further to the south. Locations of two hydrogeologic sections $\left(A-A^{\prime}\right.$ and $\left.B-B^{\prime}\right)$ are also shown (see Fig. 2 for detailed cross sections) 
concerns that the Everglades also needed to be managed for water conservation in order to supply potable water to the expanding human communities of southeast Florida. Beginning in the 1950s, additional systems of canals and levees narrowed the Everglades and blocked the flow by creating a series of basins enclosed by levees called water conservation areas (WCAs). The primary purpose of the WCAs was for water storage to support the needs for a growing population of the lower east coast of Florida, as well as a source of water to sustain Everglades National Park during dry periods. Drainage efforts had already caused irreversible subsidence by this time, and early efforts at managing the WCAs also had unintended consequences in causing periods of both flooding and drought within the Everglades. These changes to the topography and hydrology of the Everglades have altered the ecosystem in profound ways, including increasing net groundwater recharge to areas outside the Everglades that have contributed to decreasing surface-water flows. In addition, decreasing surface-water flows and deteriorating water quality are blamed for declines in wading-bird populations, disappearance of tree islands, and replacement of native plant communities by cattails (Jensen et al. 1995; McCormick et al. 1998; Rutchey and Vilchek 1999). In the past 30 years, these concerns have fueled wide-ranging discussions on how to improve water management in the Everglades. In 2000, Congress expanded authorization to preserve the Everglades' unique biological resources while continuing to address flood control and water-conservation efforts aimed at assuring the future supply of potable water for human communities of southeast Florida.

The purpose of this paper is threefold: to briefly review the past decade's advancements in understanding interactions between surface water and groundwater in the Everglades; second, to better define how groundwater's role has changed in the overall hydrologic budget of the Everglades over the past century; and third, to synthesize knowledge about groundwater's role in ecological function and sustainability of this low-nutrient subtropical floodplain ecosystem. There is increasing recognition that hydrologic inputs and their chemistry have changed substantially over the past century, and that even an alteration as seemingly innocuous as an increase in major ions has caused ecological changes.

\section{Everglades hydrogeology: past and present}

Beneath the Everglades is an extensive groundwater flow system in limestone and sand sediments of the Biscayne and Gray Limestone aquifers, known collectively as the surficial aquifer system (Fig. 2). To the east, the Biscayne aquifer is one of the most transmissive aquifers in the world serving a major metropolitan area. The Biscayne aquifer is thickest beneath the Atlantic coastal ridge and thins toward the west beneath the Everglades, disappearing completely at approximately two thirds of the distance across the Everglades. Hydrogeological investigations by Howie
(1987), Fish (1988), and Reese and Cunningham (2000) found that the surficial aquifer system beneath the Everglades generally has greater sand content, lower transmissivities, and higher total dissolved solids compared with the aquifer beneath the Atlantic coastal ridge. The marked decrease in hydraulic conductivity from east to west appears to be caused by the change from high-porosity limestones and coarser sands in the east to limestone with more variable degrees of cementation and finer sands in the western part of the Everglades. Although hydraulic conductivity of the surficial aquifer beneath the central Everglades is lower throughout most of its depth, the top $10 \mathrm{~m}$ has a hydraulic conductivity that is not substantially less than beneath the Atlantic coastal ridge (Harvey et al. 2004).

Prior to drainage that began in the early 1900s, surface water and groundwater interactions were a relatively small component of Everglades water budgets. Relatively small exchange fluxes between surface water and groundwater were due to the relatively weak driving forces for vertical flow on the pre-drainage landscape that was very flat and had not yet been altered by subsidence and the construction of canals and levees. Vertical flow resistance also was relatively high due to the continuous cap of undisturbed peat (ranging in thickness from 1-4 m) with a hydraulic conductivity several orders of magnitude lower than the aquifer beneath (Harvey et al. 2004). Recharge and discharge caused exchange between surface water and a relatively thin layer of "interactive" fresh groundwater near the top of the surficial aquifer (Harvey et al. 2006). Exchange fluxes varied spatially and temporally in accordance with changing patterns of precipitation and pulsed inflows of surface water from Lake Okeechobee or runoff from marginal wetlands. The primary factors influencing recharge and discharge were the patterns of rising or falling surface-water levels. For example, intense and localized rainfall, or pulsed inflow of water from the lake, created very low amplitude and long wavelength gravity waves that propagated southward through the wetlands causing fluctuations in surface water and groundwater interactions. Groundwater discharge tended to occur during average to moderately dry conditions when local surface-water levels were decreasing. Recharge tended to occur during moderately wet periods or during very dry periods just as water levels began to increase (Harvey et al. 2004).

Water management inadvertently increased the extent of surface water and groundwater interactions, beginning in the early 1900s with early efforts to drain the Everglades. Resulting oxidation and peat subsidence was most significant in the large area of wetlands south of Lake Okeechobee that was being drained for agriculture. Subsidence increased local groundwater discharge by focusing horizontal groundwater flow paths toward the area of subsidence and drainage. In the central Everglades, the direction of groundwater flow shifted from southerly to northwesterly flow (Miller 1988; Harvey et al. 2002). Dependence on canals increased throughout the second half of the twentieth century as the wetlands converted to agriculture continued to subside due to peat oxidation (Renken et al. 2005). Loss of peat and entrenchment of canals up to $5 \mathrm{~m}$ into the top part of 

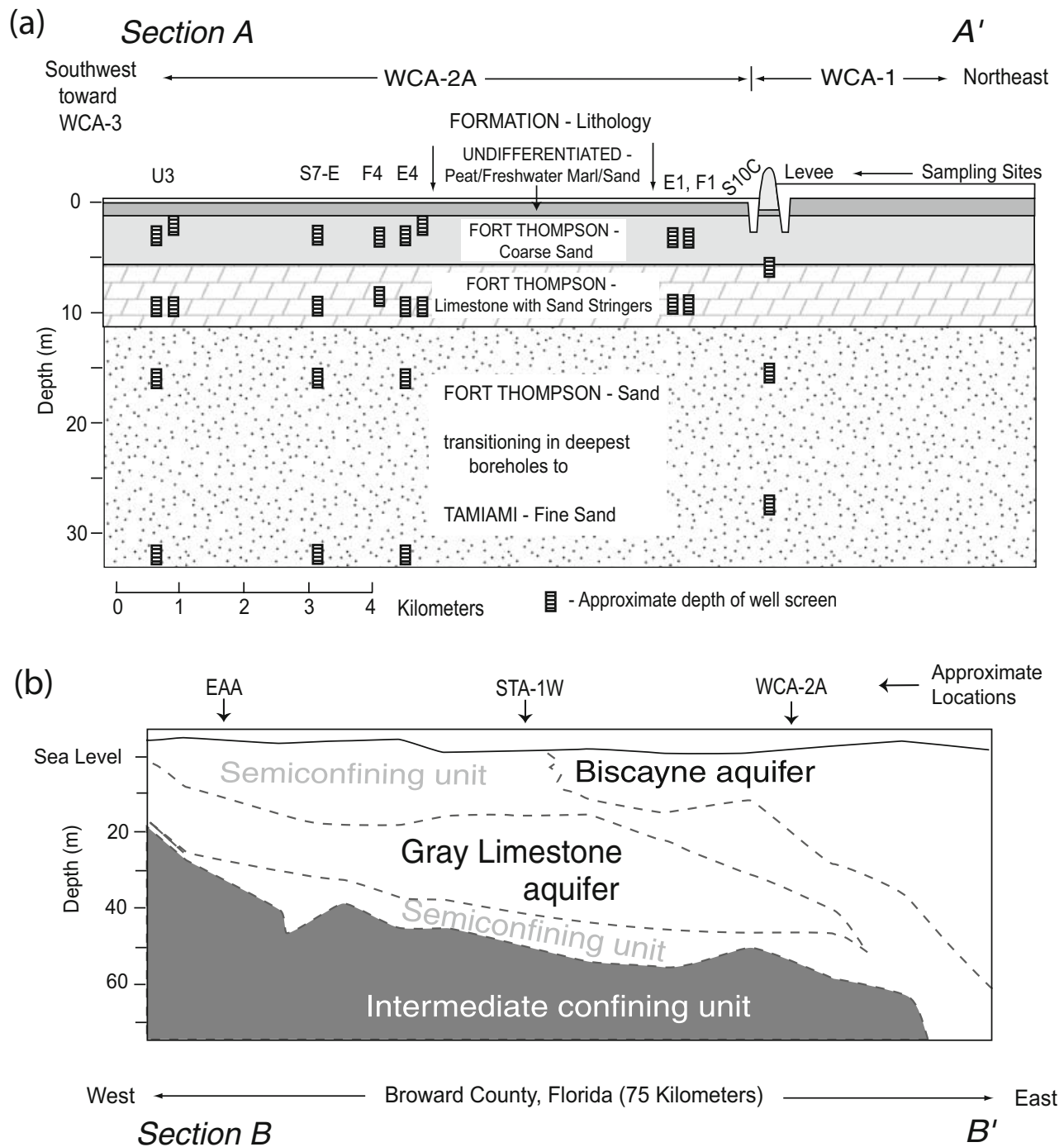

Fig. 2 Hydrogeologic cross sections in the central Everglades. a A southwesterly to northeasterly cross section ( $A-A$ ') beneath Water Conservation Area 2A (WCA-2A) shows the position of research wells in relation to formations and lithology of the western Biscayne aquifer. b Section $B-B$ ' shows a more generalized west to east hydrogeologic cross section across a 75 -km section of Broward County illustrating the large-scale features of the surficial aquifer system in southeast Florida. Approximate location relative to the different aquifer boundaries is shown for the $W C A-2 A$ groundwater investigation as well as the groundwater sampling sites in $S T A-1 W$ and the $E A A$. This figure is modified from several figures in Harvey et al. (2005)

the surficial aquifer in some locations brought surface waters into closer contact with groundwaters with high ionic strength (Harvey et al. 2002).

During the first half of the twentieth century, efforts to drain the Everglades eventually had some unintended effects on water-flow dynamics in the region. To serve the increasing need for fresh water in order to support human population growth in southeast Florida, construction began to enclose the remaining Everglades into the WCAs, beginning in the 1950s. Although effective in conserving water during dry periods, the levees introduced a discontinuity in the otherwise relatively flat water slope, by maintaining a relatively high water level on the up-gradient side of the levee and a relatively low water level on the down-gradient side. The resulting "stair-step" in water levels across levees locally increased vertical hydraulic gradients and caused recharge (on the up-gradient side) and discharge (on the down-gradient side) that brought surface water into contact with relatively deep groundwater (Harvey et al. 2002). It has also been observed that the high-capacity pumps used to move water through canals also have the unintended effect of increasing vertical hydraulic gradients in groundwater, which locally influences water exchange between canals and underlying groundwater and causes discharge of relatively deep groundwater (Miller 1978; Krupa et al. 2002).

\section{Increasing importance of groundwater in Everglades hydrologic budgets}

Because the Everglades often experiences prolonged dry seasons and multi-year droughts, freshwater can sometimes be a limited resource in this ecosystem. The thin 
lens of freshwater at the top of the aquifer (that lies above older groundwater with significantly higher ionic strength) actively exchanges with surface water on a timescale of decades to centuries (Harvey et al. 2006). This freshwater not only plays a role in sustaining the Everglades ecosystem during droughts, but the presence of different water types offers clues about the changing role of groundwater over a century of water management in the Everglades.

Appreciation of groundwater's role in Everglades hydrologic budgets increased greatly after early efforts to achieve flood control were expanded to include water conservation. Much of what has been learned about groundwater and surface-water interactions in the Everglades has its basis in the SFWMM, i.e. South Florida Water Management Model (SFWMD 1999; 2003). The SFWMM has been a primary management tool for watermanagement and restoration planning (US Army Corps of Engineers 1999). The SFWMM also served as the basis of the Natural Systems Model (NSM), a daughter model that had the purpose of hindcasting a typical water budget in the pre-drainage Everglades (SFWMD 2006). The NSM does not actually attempt to simulate a specific time period, and instead operates with the standard 31-year input series of precipitation data and evapotranspiration functions used for what is referred to as the 1995 base run of the SFWMM (SFWMD 1999, 2003). The difference is that the NSM uses the best available estimates of predrainage topography, vegetation distribution, vegetative flow-resistance, and tidal and inflow boundaries. Therefore, NSM and SFWMM outputs can be directly compared to illustrate differences between the current managed system and the pre-drainage system under identically modeled climatic conditions.

The boundaries defined for the pre-drainage Everglades are the historic areas of contiguous emergent wetlands lying between Lake Okeechobee to the north and Everglades National Park to the south (SFWMD 2006). The boundaries for the present-day central Everglades are the same as the WCAs that collectively make up the northern and central portion of the managed Everglades system (Fig. 1). These boundaries are formally defined by the SFWMD (1999, 2006). The major difference in the predrainage Everglades system is the inclusion of the northernmost areas of former wetlands that were later converted to agricultural lands known as the Everglades Agricultural Area (EAA) (Fig. 1). The southern boundary of this comparison is the present-day southern boundary of WCA-3, which is located where Highway 41-Tamiami Trail crosses the Everglades. Everglades National Park water budgets are therefore not a part of the analysis.

In this study, the model results were used to identify changes in the relative importance of various water sources over the past century. Given the spatially and temporally averaged nature of the hydrologic budgets, the following results should be interpreted with caution. The relative contributions from different water sources are expected to vary considerably between specific locations in the Everglades and also among years.

The resulting water budget (Table 1) indicates that direct rainfall was the primary source $(81 \%)$ of water to the pre-drainage Everglades, with additional contributions originating as episodic overflows of Lake Okeechobee, marginal runoff that occurred seasonally from infrequently flooded wetlands surrounding the Everglades, and exchange with groundwater in the underlying sand and limestone aquifer. Lake Okeechobee and marginal inflows contributed 8 and $10 \%$ of the total input, respectively. Net groundwater discharge and recharge fluxes denote groundwater flow paths near the margins of the Everglades that either receive water or deliver water to areas outside the Everglades. The net groundwater fluxes were small in the pre-drainage system (1\%). These estimates of groundwater fluxes from SFWMD references do not include a second category of groundwater recharge and discharge fluxes. The second type of groundwater fluxes are shallow recharge and discharge fluxes that occur internally within the boundaries of the Everglades. Interior groundwater fluxes were also estimated based on 5 years of Darcy-flux

Table 1 Sources of water inflow and output patterns and their relative importance in the North-Central Everglades ${ }^{\mathrm{a}}$

\begin{tabular}{|c|c|c|c|c|}
\hline \multirow[t]{2}{*}{ Landscape condition } & \multicolumn{2}{|c|}{$\frac{\text { Pre-drainage Everglades }}{\text { Model NSM v. } 4.5}$} & \multicolumn{2}{|c|}{$\begin{array}{l}\text { Present-day managed Everglades } \\
\text { Model SFWMM v. } 3.5\end{array}$} \\
\hline & $10^{7} \mathrm{~m}^{3}$ per year & $\%$ of total inputs & $10^{7} \mathrm{~m}^{3}$ per year & $\%$ of total inputs \\
\hline \multicolumn{5}{|l|}{ INPUTS } \\
\hline Precipitation & 742 & $81 \%$ & 426 & $66 \%$ \\
\hline Lake overflow & 75 & $8 \%$ & 28 & $4 \%$ \\
\hline EAA drainage & - & - & 113 & $18 \%$ \\
\hline Marginal inflows & 92 & $10 \%$ & 76 & $11 \%$ \\
\hline Net groundwater discharge & 8 & $1 \%$ & 4 & $1 \%$ \\
\hline \multicolumn{5}{|l|}{ OUTPUTS } \\
\hline ET & 675 & $74 \%$ & 413 & $64 \%$ \\
\hline Marginal outflows & 229 & $25 \%$ & 124 & $19 \%$ \\
\hline Net groundwater recharge & 10 & $1 \%$ & 106 & $16 \%$ \\
\hline Storage change & 4 & $0 \%$ & 4 & $1 \%$ \\
\hline
\end{tabular}

${ }^{\text {a }}$ Results were summarized from South Florida Water Management District model runs made using Natural Systems Model v. 4.5 and South Florida Water Management Model v. 3.5 (all runs dated 4 April 1999) that were accessed 20 December 2006 from the web (SFWMD 2003) and from calculations made using results from Harvey et al (2005). Dashed table entries are not applicable 
calculations in WCA-2A and tritium data (Harvey et al. 2005). While interior exchange fluxes with groundwater are small $(2 \%)$ relative to total inflows, exchange fluxes with wetland peat are greater (39\%). Note that although these interior fluxes are not included in Table 1, they potentially could be important to Everglades chemical budgets with consequences for Everglades water chemistry and ecology (Harvey et al. 2005).

Changes over time in Everglades water budgets are summarized here. The importance of precipitation as a water source decreased (from 81 to $66 \%$ ) in the managed Everglades while at the same time the surface-water inflows increased from 18 to $33 \%$. Canal drainage from agricultural areas that were formerly wetlands (the EAA) increased the most ( 0 to $18 \%$ ), marginal inflows stayed about the same (10 and $11 \%$ respectively), and direct inputs from Lake Okeechobee decreased slightly (from 8 to $4 \%$ ). The canal drainage waters are themselves derived from a mixture of runoff of precipitation and Lake Okeechobee water used for irrigation, and possibly also from groundwater beneath the EAA that discharged to canals. The other significant change in the water budget was a substantial increase (from 1 to $16 \%$ of total inputs) in net recharge of Everglades groundwater that then flows to areas outside the Everglades. For the purpose of clarification, it is important to note that the raw precipitation and evapotranspiration (ET) values differed between the NSM and SFWMM models only because the land area involved changed.

\section{Increasing chemical inputs to the central Everglades}

Hydrologic budgets indicated a relative increase in contributions from surface-water inflows over the past century, especially from canals draining the EAA, and a relative decrease in contributions from precipitation. Surface-water inflows are inherently higher in their ionic strength than precipitation, and human activities directly and indirectly increased those mineral and nutrient inputs further with consequent effects on the biological communities of the Everglades. An evaluation of present-day chemical data in the Everglades does not necessarily reveal how hydrologic alterations affected the Everglades. For this reason, the study evaluated both groundwater and surface-water chemistry in order to take advantage of groundwater's tendency to average chemical signatures over time due to the relatively long storage times (decades to centuries) in shallow groundwater (Harvey et al. 2006). Here, necessary background information about chemical conditions in the Everglades are briefly reviewed, based on chemical sampling and analyses by Parker et al. (1955), Harvey et al. (2002), (2005), and data obtained from the electronically accessible database of the SFWMD (SFWMD 2008). Following that, water stable isotope and ionic tracers were used to assess the relative importance of the various sources to increasing mineral inputs to the Everglades.

\section{Mineral chemistry of peat}

Historical reconstructions of the Everglades have primarily been based in paleoecological analyses of peat. These approaches are generally best at identifying century to millennial timescale trends. Everglades peat began forming about 5,000 years ago on top of limestone bedrock in a shallow trough across south Florida. Like most other peatlands, the Everglades is relatively poor in nutrients and minerals. Although limestone dissolution influenced water chemistry in the early stages of peat development, there is evidence that much of the northern and central Everglades was developing towards an increasingly mineral-poor state as peat built up in thickness during the shift towards a wetter climate in south Florida (Gleason et al. 1974; Gleason and Stone 1994). Although increasing thickness of peat is not alone enough to isolate surface water from interactions with groundwater that is high in ionic strength (Siegel and Glaser 1987), it does contribute to isolation in a landscape as flat as the Everglades. Another indication of increasing isolation of surface waters from mineral sources is the "water lilydominated peat" found in the central and northeastern Everglades, which has only minor amounts of marl, i.e. intervening layers of calcitic mud with moderate to high mineral content, that is more commonly associated with the thin, and less frequently flooded peat found in the marl prairies in the southern Everglades (Gleason and Stone 1994; Slate and Stevenson 2000; Winkler et al. 2001).

\section{Precipitation}

Rainfall in the northern and central Everglades is low in ionic strength with a median specific conductance of less than $20 \mu \mathrm{S} / \mathrm{cm}$ and median concentrations of all major ions below $1 \mathrm{mg} / \mathrm{L}$ except for $\mathrm{Cl}^{-}(1.5 \mathrm{mg} / \mathrm{L})$ and $\mathrm{SO}_{4}{ }^{2-}$ $(1 \mathrm{mg} / \mathrm{L})$. In the absence of significant water sources other than direct rainfall, surface waters of the Everglades would have a mineral-poor chemistry. Rainfall has a sodium calcium-bicarbonate chloride signature (Fig. 3) reflecting the importance of seawater aerosols to the ionic strength, with additions of locally generated dust and other fine particles associated with farming and other human activities. Spatial patterns in precipitation have been important in structuring water budgets. The highest average annual precipitation (approximately $160 \mathrm{~cm} /$ year) extends far inland (up to $60 \mathrm{~km}$ ) in the northeastern part of the Everglades but farther south the band of greater precipitation remains much closer to the coast until reaching Florida Bay. Greater rainfall in the northeastern Everglades may be one reason for the development of the relatively deep and distinctive water-lily-dominated peat in the northeastern Everglades (Gleason et al. 1974).

\section{Wetland surface waters}

The northeastern apex of the historic Everglades is now a major part of the area occupied by WCA-1 and WCA-2A. Because of their position, marginal inflows of surface water may have exerted a greater influence on WCA-1 and 


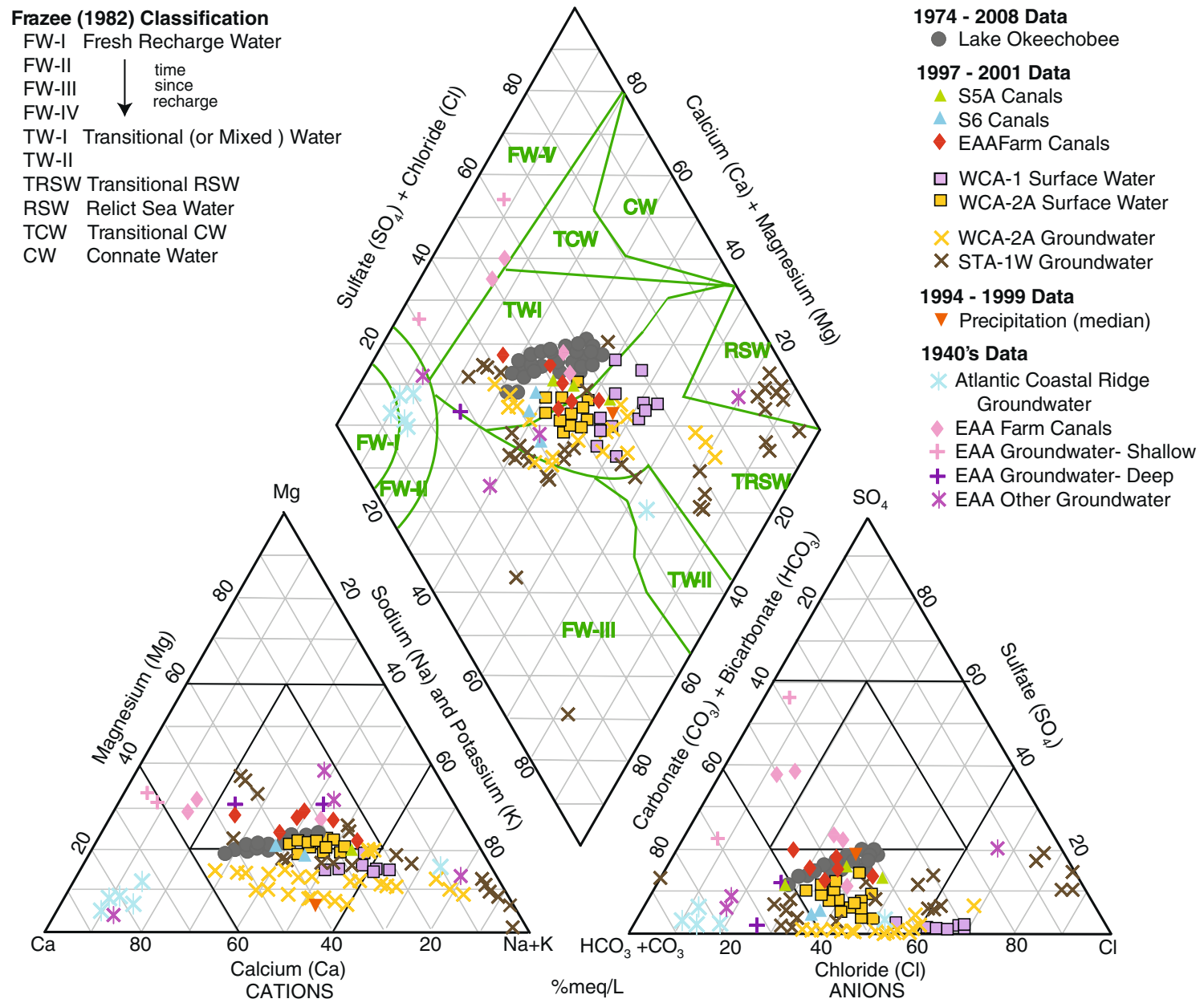

Fig. 3 Piper diagram illustrating variability in major ion composition for the various surface water and groundwater samples collected within or immediately outside of the Everglades. Data include published analyses on water samples collected from 1974 to 2008 (SFWMD; Harvey et al. 2002, 2005), as well as some of the earliest available water chemistry data for the Everglades from samples collected in the 1940s (Parker et al. 1955)

WCA-2 compared with areas farther to the west (i.e. now occupied by the EAA and WCA-3A), where overflow from Lake Okeechobee was probably the more important surface-water inflow. Under present management, WCA$2 \mathrm{~A}$ sometimes receives the majority of its water from canal drainage delivering mixtures of EAA farm canal runoff and Lake Okeechobee water. In contrast, WCA-1 is mostly isolated from canal waters and from marginal inflows due to complete enclosure by levees and without any flow-through pumping. For that reason, the interior of WCA-1 and WCA-2A currently represent the extremes of water chemistry of wetland surface waters in the northern and central Everglades. WCA-1 surface water is a sodium calcium-chloride bicarbonate water type and WCA-2A is a mixed cation-chloride bicarbonate water type. The chemistry of WCA-1 surface water indicates an initially significant contribution from seawater aerosols in precipitation that was further altered by addition of limestone dissolution products due to interactions with shallow groundwater. WCA-2A has a considerably higher specific conductance (with a median $946 \mu \mathrm{S} / \mathrm{cm}$ in WCA-2A compared to $92 \mu \mathrm{S} / \mathrm{cm}$ in WCA-1). WCA-2A also has greater relative contributions from $\mathrm{Mg}^{2+}$ to cations and $\mathrm{SO}_{4}{ }^{2-}$ to anions, reflecting inputs from EAA drainage canals and Lake Okeechobee (Fig. 3).

\section{Water inputs from Lake Okeechobee}

Historically, Lake Okeechobee overflowed each wet season and provided a significant source of water to the pre-drainage Everglades (Chris McVoy, SFWMD, personal communication 2006; Table 1). A dike now prevents overflows, with a system of levees and canals to control deliveries of lake water to the Everglades. EAA canals route lake water primarily through the S6 water control structure to be discharged into WCA-2A. The lake has a specific conductance of approximately $400-500 \mu \mathrm{S} / \mathrm{cm}$, and relatively even proportions of $\mathrm{Ca}^{2+}$ and $\mathrm{Na}^{+}$, with some $\mathrm{Mg}^{2+}$, and relatively even proportion of $\mathrm{HCO}_{3}{ }^{-}$and $\mathrm{Cl}^{-}$, with some $\mathrm{SO}_{4}{ }^{2-}$, resulting in a classification as a mixed cation-bicarbonate chloride water type (Fig. 3). The lake's chemistry is primarily influenced by runoff from the Kissimmee River basin and secondarily by interactions with lakebed sediments and groundwater. 
Groundwater in the lake's vicinity has higher proportional contributions from $\mathrm{Ca}^{2+}$ and $\mathrm{Mg}^{2+}$ and lower contributions from $\mathrm{Cl}^{-}$and $\mathrm{SO}_{4}{ }^{2-}$ to its dissolved solids compared to Lake surface water. Back-pumping from EAA farm canals to the lake may have influenced the lake's chemistry during certain time periods due to agricultural influences, but is not expected to dominate Lake chemistry.

\section{Marginal runoff from infrequently flooded wetlands and low-lying uplands}

The chemical composition of drainage from infrequently flooded wetlands or low-lying uplands such as pine flatwoods to the pre-drainage Everglades is uncertain. In the northern and central areas of the Everglades these marginal areas have been altered so substantially in their topography and hydrology that finding a modern analog is difficult. It is instructive to look at the southern Everglades where there are large areas of short hydroperiod wetlands on the margins of the major sloughs in Everglades National Park. The relatively short hydroperiods in those areas promote infiltration of precipitation into the peat and bedrock (Price and Swart 2006). The wetlands also have thinner peat accumulations (Gleason et al. 1974) which offers less resistance to subsurface vertical flow. Surfacewater specific conductance in the most mineral-rich freshwater areas of Everglades National Park rarely exceeds 400-600 $\mathrm{\mu S} / \mathrm{cm}$ (Joffre Castro, Everglades National Park, personal communication, 2007). The relatively high transmissivity of the Biscayne aquifer beneath the southern Everglades (Fish and Stewart 1991; Renken et al. 2005) and the thinner peats in the southern Everglades promote significant flow through marginal wetlands into the sloughs of the southern Everglades (Price et al. 2003; Harvey et al. 2006). The chemistry of shallow groundwaters in short hydroperiod wetlands (Price and Swart 2006) is similar to the subset of eastern canal waters in the northern Everglades that have lower specific conductance, i.e. calcium sodium-bicarbonate waters. Short hydroperiod wetlands in Everglades National Park are therefore one of the potential models for chemistry of marginal runoff entering the pre-drainage Everglades.

\section{Groundwater}

Deeper groundwater in the western part of the Biscayne aquifer beneath WCA-2A has a specific conductance often above $10,000 \mu \mathrm{S} / \mathrm{cm}$ and as high as $26,000 \mu \mathrm{S} / \mathrm{cm}$ and is a sodium chloride water type, reflecting its origin as relict seawater trapped in the aquifer during higher sea level stands (Howie 1987; Harvey et al. 2002; Price and Swart 2006). The origin of the shallow groundwater is very different. Groundwater in the top $10 \mathrm{~m}$ of the western Biscayne aquifer typically is a calcium sodium-bicarbonate type water with a specific conductance of about $1,250 \mu \mathrm{S} / \mathrm{cm}$ and a chemical and isotopic composition indicating a source from recharge of evaporated Everglades surface water that slowly acquired a predominantly $\mathrm{Ca}^{2+}, \mathrm{Mg}^{2+}$, and $\mathrm{HCO}_{3}{ }^{-}$ signature due to dissolution of shallow aquifer materials.
Sulfate reduction removed $\mathrm{SO}_{4}{ }^{2-}$ from the shallow groundwater (Fig. 3). Depending on depth and location relative to water management structures and levees, the ionic strength of shallow groundwater may be elevated by $\mathrm{Na}^{+}$and $\mathrm{Cl}^{-}$due to upward discharge of deeper groundwater. Near canals and levees, shallow groundwater, peat pore water, and even canal water and Everglades surface water can have a chemical signature that traces the upward movement and discharge of relict seawater (Miller 1988; Harvey et al. 2002; Krupa et al. 2002)

Groundwater composition beneath WCA-2A transitions from the western Biscayne aquifer, with relict seawater in its lower half, to a different (unnamed) surficial aquifer beneath the EAA and Lake Okeechobee which contains a mixed cation-bicarbonate groundwater at depth. The deeper groundwater in both aquifers is relatively high in ionic strength, but the proportions of $\mathrm{Ca}^{2+}, \mathrm{Mg}^{2+}, \mathrm{SO}_{4}{ }^{2-}$, and $\mathrm{Cl}^{-}$ differ (Fig. 3). Groundwater in the lower Biscayne aquifer beneath WCA-2A is either a sodium-chloride or sodium calcium-chloride bicarbonate type water. Deeper groundwater beneath the EAA/Lake is distinctive in having higher proportional contributions from $\mathrm{Ca}^{2+}$ and $\mathrm{Mg}^{2+}$, and lower proportional contributions from $\mathrm{Cl}^{-}$, compared to Biscayne aquifer water (Fig. 3). Whereas groundwater in the Biscayne aquifer beneath WCA-2A was derived both from freshwater recharge of Everglades surface water and trapping of relict seawater at depth, the groundwater beneath the EAA/Lake was derived only from recharge of freshwater from the Kissimmeee River basin. Fresh groundwater beneath the EAA and Lake differs in chemistry due to longer contact time with different aquifer materials.

Groundwater samples beneath Stormwater Treatment Area 1W (STA-1W) represent a transition between the Biscayne aquifer and the EAA/Lake Okeechobee surficial aquifer. STA- $1 \mathrm{~W}$ is located $40 \mathrm{~km}$ north of the center of WCA-2A, between WCA-1 to the east and the EAA to the west. As a result of its intermediate location, STA-1W groundwater chemical samples either represent relict seawater, sodium chloride-bicarbonate type waters characteristic of shallow groundwater in the Biscayne aquifer, or mixed cation-bicarbonate type waters found in the surficial aquifer beneath the EAA and the lake (Fig. 3).

Frazee (1982) suggested but offered no direct evidence that transitional connate groundwater with a relatively high proportional contribution from $\mathrm{SO}_{4}{ }^{2-}$ is present in the vicinity of the lake. The authors' search of published data revealed no evidence of such a groundwater within the study boundaries, although shallow groundwater in the EAA, while similar to the deeper groundwater in most respects, does have a greater proportional contribution from $\mathrm{SO}_{4}{ }^{2-}$ compared with $\mathrm{Cl}^{-}$. Sulfur budgets in the EAA have been influenced by agricultural activities for many decades. Excess $\mathrm{SO}_{4}{ }^{2-}$ in EAA groundwater appears to have resulted from agricultural practices which produced a shallow groundwater that could be mistaken for a transitional connate groundwater (Fig. 3). This interpretation is supported in the next section and in a section further ahead that uses environmental solute tracers to distinguish water sources. 


\section{Canal inflows to the Everglades}

Canal waters are an important source of water and dissolved materials to the managed Everglades ecosystem. The most significant sources are the main conveyance canals flowing into the Everglades (the West Palm Beach, Hillsboro, North New River, and Miami canals shown in Fig. 1). These canals convey runoff of rainfall, soil water, and groundwater discharge from agricultural fields in the EAA as well as flow-through waters from Lake Okeechobee into the northern and central Everglades.

The influence of canals as inputs of waters with high ionic strength is evident from spatial maps of surfacewater specific conductance in the Everglades wetlands generated from the Regional Environmental Monitoring and Assessment Program (REMAP) conducted by the US Environmental Protection Agency (Stober et al. 1998). The median specific conductance of surface waters in the main canals ranges between $700-1,100 \mu \mathrm{S} / \mathrm{cm}$, more than 50 -fold higher than that of rainfall and twice that of current levels in Lake Okeechobee, which also is exposed to elevated mineral loads from human sources. Areas strongly influenced by canal inputs have a specific conductance near $1,000 \mu \mathrm{S} / \mathrm{cm}$ (e.g. WCA-2A), while those with a more rainfall-driven hydrology typically have values as low as $100 \mu \mathrm{S} / \mathrm{cm}$ or less (e.g. WCA-1). Specific conductance decreases from north to south across the Everglades canal network. This trend likely is caused by progressive dilution with rainwater and surface waters in the WCAs with increasing distance from the mineral sources in the north.

The chemical composition of canal water draining the EAA varies at water control structures that convey the water into the Everglades. The westernmost canals passing through the S7 and S8 structures generally contain only EAA drainage waters, while canals passing through S6 (and sometimes S5A) convey lake water in addition to farm canal drainage. The $\mathrm{S} 5 \mathrm{~A}$ structure receives the broadest mix of water types, including canal drainage from the EAA, Lake Okeechobee water, and drainage from the low-lying basins to the east of Lake Okeechobee. For this reason, the S5A canal may at certain times be the best analog of what the chemistry of low-lying marginal areas was like in the pre-drainage central Everglades. The specific conductance in S5A ranges between 400 and $1,400 \mu \mathrm{S} / \mathrm{cm}$; samples with conductance less than $900 \mu \mathrm{S} / \mathrm{cm}$ can be classified as calcium bicarbonate or calcium-sodium bicarbonate water that is relatively poor in sulfate and possibly representative of pre-drainage marginal inflows (Harvey et al. 2002). The samples with specific conductance greater than $900 \mu \mathrm{S} / \mathrm{cm}$ have proportionately greater importance of magnesium and sulfate that probably reflect large contributions from EAA canals at those times.

Compared with other water sources to the Everglades, canal water has substantially higher contributions of $\mathrm{Mg}^{2+}, \mathrm{SO}_{4}{ }^{2-}, \mathrm{Ca}^{2+}$, bicarbonate, and lower $\mathrm{Na}^{+}$and $\mathrm{Cl}^{-}$ compared to Everglades surface water or groundwater, or Lake Okeechobee surface waters (Fig. 3). EAA canal drainage water tends to have too great of a contribution from $\mathrm{SO}_{4}{ }^{2-}, \mathrm{Ca}^{2+}$ and too little of a contribution from $\mathrm{Cl}^{-}$ to be explained by deeper EAA/Lake Okeechobee groundwater or STA-1W groundwater. Chemical sampling in the 1940s indicates that shallow EAA groundwater also was rich in $\mathrm{SO}_{4}{ }^{2-}$ and $\mathrm{Ca}^{2+}$ and similar to the chemistry of EAA farm canals while also being very different from Lake Okeechobee surface water and all other groundwaters in the vicinity (Fig. 3). The chemical uniqueness of EAA canal drainage waters has been noted before and attributed to flushing of peat oxidation products (Schueneman 2001) and flushing of fertilizer additives (Bates et al. 2002) from farm fields. Those agricultural influences also could have affected the shallow EAA groundwaters directly beneath the farm fields through recharge of peat oxidation products and agricultural fertilizer additives through farm fields into shallow groundwater. The irrigation water and precipitation that recharges farm fields would move into shallow groundwater and eventually discharge into drainage canals that flow to the Everglades. The next section discusses the use of environmental solute tracers to distinguish the relative importance of these various sources of water to the Everglades.

\section{Use of environmental solute tracers to delineate water sources}

This section combines chemical signatures with the hydrologic budgets already presented to determine changing water sources and chemical inputs to the Everglades on a decadal to centennial timescale. Environmental solute tracers are used as a means to isolate the effects that water management has had on changing chemistry and ecology.

\section{Water stable isotopes}

Samples of precipitation, surface water, groundwater, and canal water collected between 1996 and 2000 in the Everglades and its source waters were analyzed for water stable isotopes (deuterium and ${ }^{18} \mathrm{O}$ ) reported as $\delta{ }^{2} \mathrm{H}$ and $\delta^{18} \mathrm{O}$ in $\%$ units relative to the international standard VSMOW in order to help distinguish the relative importance of different water sources (Fig. 4). Whereas the precipitation isotope ratios plot along the global meteoric water line in the negative range of isotopic values, most of the other isotopic data are positive values, plotting on a line of lower slope that subtends the global meteoric water line.

Of the various surface waters, wetland surface water in the Everglades is the most variable in composition, ranging between values close to precipitation during the wet season to much more positive values during the dry season. The data illustrate the importance of direct precipitation on the Everglades with more negative water-stable isotope compositions reflecting the primary input during the wet season. Evaporation also strongly influences isotopic composition during much of the year, enabling differentiation between evaporated surface water and groundwater as the source of shallow groundwater. 


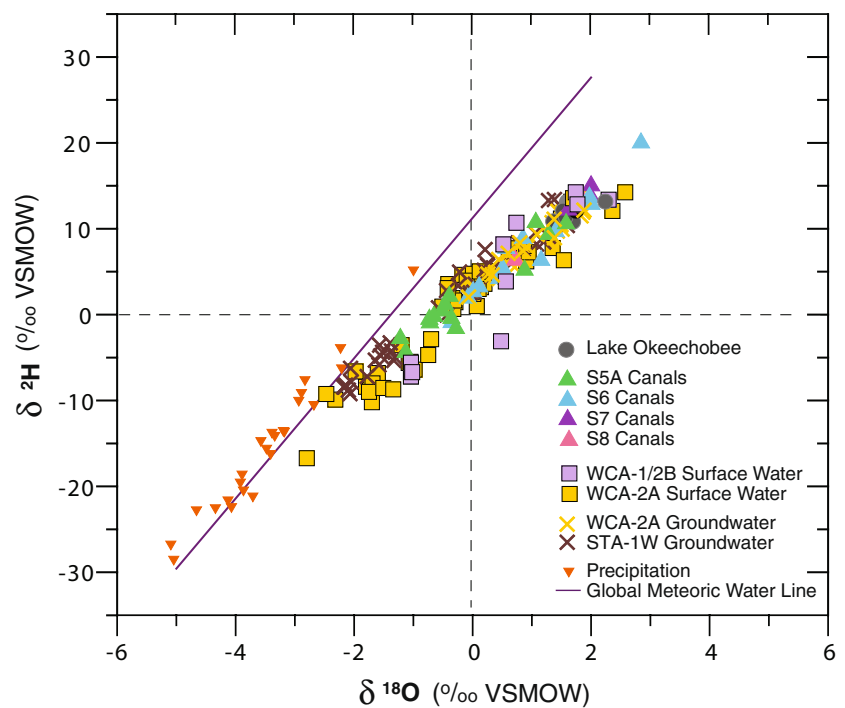

Fig. 4 Water stable isotope ratios (in \% relative to VSMOW) for Everglades surface waters, groundwaters, and source waters. The Everglades isotopic data were compiled from Harvey et al. (2002; 2005 ) with additional isotopic data for Lake Okeechobee and some canals provided by Bill Orem (USGS, unpublished data, 2007)

The relatively positive isotopic values of WCA-2A surface waters during the dry season are consistent with evaporation effects, but also may reflect mixing with other evaporated surface waters (e.g. Lake Okeechobee or canal drainage from the EAA).

Canal waters from the EAA passing through the S6 structure are similar in enrichment to Lake Okeechobee, with other canals being slightly more negative in isotopic composition (Fig. 4). The more positive isotopic composition of S6 canal waters is consistent with routing of Lake Okeechobee water primarily through the S6 structure. Lower isotopic values in the $\mathrm{S} 5 \mathrm{~A}$ and other canals probably reflect additional components of runoff generated by flushing of rainfall through EAA soils and shallow groundwater to the larger EAA canals that discharge directly into the Everglades. Unfortunately, there are no direct measurements of EAA soil water or shallow or deep groundwater under most of the EAA. Groundwater beneath STA-1W, which is located on the margin between the EAA and the WCAs, is the only water stable isotope data available that may be informative about hydrologic differences between pre- and post-drainage groundwater hydrology in the EAA.

Most STA-1W groundwater is relatively enriched, however a smaller subset of the shallow STA-1W groundwater samples located on its western side have more negative isotopic values that are much closer to precipitation (Fig. 4). Similar values of water stable isotope ratios close to precipitation values also have been observed in shallow groundwater beneath short hydroperiod wetlands of the Rocky Glades in the southern Everglades by Price and Swart (2006). The more negative isotopic composition of those waters is consistent with recharge of precipitation occurring quickly and without time for significant evaporation to occur (Harvey et al.
2002; Price and Swart 2006). In STA-1W those values reflect the history of the area as part of the EAA, where drainage and farming in the middle part of the century promoted direct infiltration of precipitation into soils until the mid 1990s when the site was re-flooded for operation as a stormwater treatment area.

The WCA-1 and WCA-2B basins were isolated from surface-water throughputs and only received water input by precipitation during the time period of sampling. The observation that both of the isolated basins vary just as broadly in their water stable isotope ratio compared with WCA-2A is significant, because WCA-2A receives isotopically enriched inputs from EAA canal drainage that includes Lake Okeechobee water. Evaporation effects on the isotopic chemistry of Everglades surface water therefore have comparable effects to mixing of source waters, i.e. mixing of precipitation with Lake Okeechobee and canal drainage waters. Discharge of deeper groundwater from the western Biscayne aquifer beneath WCA-1 and WCA-2 also has more positive water stable isotope composition, somewhat fortuitously, because seawater trapped in the Biscayne aquifer in south Florida plots on almost exactly the same line as evaporated waters (Price and Swart 2006) (Fig. 4). Because of the similarity of the mixing line along which many of the different waters plot (e.g., canals waters draining the EAA, Lake Okeechobee water, relict seawaters, and evaporated precipitation), water stable isotopes cannot delineate all potential mixing effects. Additional environmental tracers are needed to better delineate the contribution of groundwater from beneath the EAA to EAA canal drainage that flows into the Everglades.

\section{Ionic tracers}

Sulfate to chloride ratios have been used previously to help distinguish sources of Everglades waters (Bates et al. 2002; Chen et al. 2006). In particular, WCA-2A surface waters have a ratio of sulfate to chloride that is very similar to the canals draining the EAA and much higher than in the relict seawater at depth in the western Biscayne aquifer. The ratio of sulfate to chloride is also much higher than in shallow groundwater beneath WCA-2A, whose source is surface water from the Everglades that was recharged decades to centuries ago (Harvey et al. 2006). The very low ratio of sulfate to chloride in shallow groundwater beneath WCA-2A is also consistent with sulfate removal by sulfate reduction (Bates et al. 2002). Lake Okeechobee waters also have a high sulfate to chloride ratio, although Orem (2007) noted that Lake Okeechobee water is too dilute in these ions to be the major water source to WCA-2A surface water during most times of year. These results are strong indicators that EAA canal waters are a significant source of WCA-2A surface water, comparable in importance to precipitation, and the most likely source of increased sulfate and increased mineral inputs in general to the central Everglades. Left somewhat in question is the ultimate source of the increased mineral loads in canals draining the EAA. 
Both the products of peat oxidation (Schueneman 2001) and fertilizer additives (Zielinski et al. 2000; Bates et al. 2002; Chen et al. 2006) have been investigated as indicators of the water and chemical sources in canals draining the EAA. The importance of fertilizer and fertilizer additives was established through use of uranium isotope ratio tracers that identified EAA fertilizer as the source of elevated P and sulfate to EAA canals as well as in Everglades surface waters (Zielinski et al. 2000). In a study using sulfur isotopes as an environmental tracer of water flow, Bates et al. (2002) and Orem (2007) found that sulfate in Everglades surface waters and EAA canal waters had a ${ }^{34} \mathrm{~S} /{ }^{32} \mathrm{~S}$ ratio similar to fertilizer. The sulfur isotopic ratio and sulfate concentration measured in shallow groundwater beneath WCA-2A are too high and too low, respectively, to explain the source of sulfate in EAA canal water (Bates et al. 2002). Unfortunately, there were no isotope ratio measurements made in groundwater beneath the EAA to help explain the source of excess sulfur to EAA canals. Instead, one must rely on major ion ratios to delineate the importance of groundwater discharge from directly beneath the EAA to canals entering the Everglades.

As discussed earlier in this paper, deep groundwater from beneath the EAA and Lake is mixed cationbicarbonate water with relatively high ionic strength, but that groundwater is relatively poor in both chloride and sulfate, and discharge of that groundwater cannot explain new mineral sources to the Everglades. According to Renken et al. (2005), Lake Okeechobee has long served as a source of irrigation water in the EAA, which explains why the chemistry of EAA canals often is similar to Lake Okeechobee. However, farm canals in the EAA (as well as shallow, but not deeper, groundwater beneath the EAA) have been observed to have significantly higher concentrations $\mathrm{SO}_{4}{ }^{2-}$ relative to the lake (Orem 2007). Using isotopic ratios of $\mathrm{SO}_{4}{ }^{2-}$ and $\mathrm{Ca}^{2+}$ relative to $\mathrm{Cl}^{-}$, it was observed that EAA farm canals and shallow groundwater had a chemical composition that could be explained by enrichment of Lake Okeechobee water with stoichiometrically equivalent additions (i.e., mass ratio of 2.4) of $\mathrm{SO}_{4}{ }^{2-}$ and $\mathrm{Ca}^{2+}$ (Fig. 5). The unique plotting position of EAA farm canals and shallow EAA groundwater in Fig. 5 relative to other prominent south Florida water types is suggestive of their origin as irrigation water derived from Lake Okeechobee water that had further modifications to its chemistry by dissolution of gypsum, a commonly used fertilizer additive.

Gypsum is applied to southeastern US agricultural soils, including EAA soils, to improve structure and fertility. Schueneman (2001) recently quantified the use of sulfur additives in EAA fertilizer and suggested that current sulfur application rates on farm fields are probably low relative to oxidation of naturally occurring sulfur in EAA peat. Sulfate leaching resulting from oxidation of naturally occurring sulfur in peat soils has probably been occurring since the early 1910 s, and may be a significant contributor to the high concentrations of sulfate that have been observed in EAA canals (Orem 2007). Nonetheless, Fig. 5 demonstrates a substantial source of $\mathrm{SO}_{4}{ }^{2-}$ to EAA

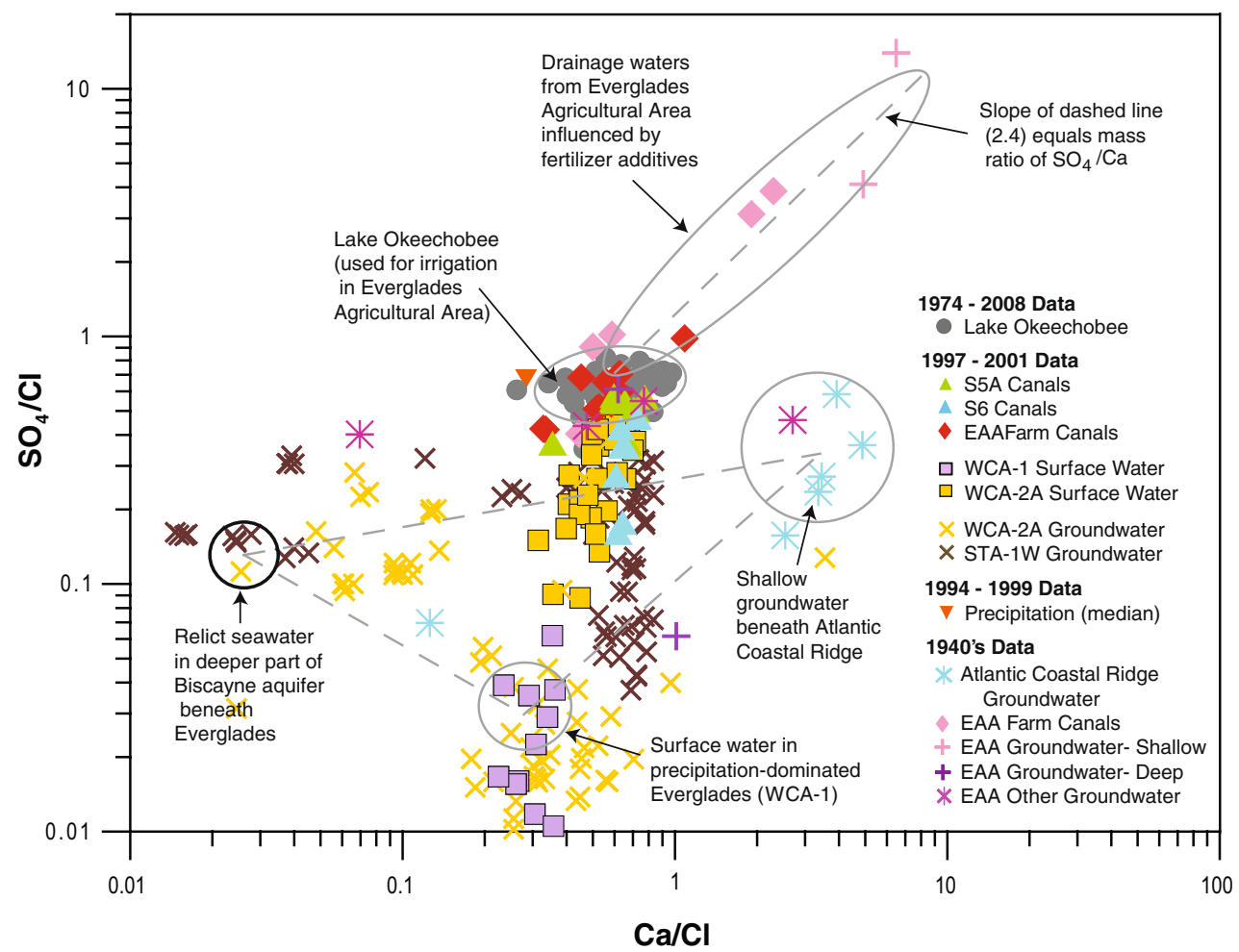

Fig. 5 Comparison of sulfate and calcium in Everglades surface waters, groundwaters and source waters. Sulfate and calcium concentrations $(\mathrm{mg} / \mathrm{L})$ are normalized with respect to chloride concentrations, which distinguish relict seawater based on well-known ionic ratios. Other distinguishable water types are noted. The data sources are the same as Fig. 3 
surface water and shallow groundwater in the 1940s that cannot be explained by any source except dissolution of gypsum, and gypsum is only one possible source of $\mathrm{SO}_{4}{ }^{2-}$ in fertilizer additives. The other is oxidation of the elemental sulfur, which is another common additive in fertilizer used in the EAA (Bates et al. 2002). Schueneman (2001) states that current applications of sulfur to EAA farm fields are in quantities less than recommended amounts. Figure 5 does suggest that the effects of gypsum dissolution on EAA canal chemistry are smaller today than in the 1940s. It may be that gypsum applications were greater in the early decades of EAA farming, when it would have had its greatest value to increase soil structure, oxidation, and fertility. It is possible that more recent applications of sulfur may be in elemental sulfur form (Bates et al. 2002; Orem 2007). Additional research would be needed to distinguish the relative importance of the various sources with confidence. In particular, more chemical sampling is needed in EAA shallow groundwater to increase certainty in present-day sulfur budgets for the EAA and the Everglades.

The foregoing discussion and accompanying figures demonstrate that increased mineralization of EAA surface water was already well advanced in the 1940s. Zielinski et al. (2000) and Bates et al. (2002) found by using uranium isotopes and sulfur isotopes respectively as tracers, that a significant proportion of new mineral sources (sources of phosphorus and sulfur specifically) were derived from agricultural activities in the EAA. With drainage and conversion of wetlands to agriculture beginning early in the $1910 \mathrm{~s}$, prior to the availability of reliable chemical measurements, the pre-drainage water chemistry in the northern part of the Everglades now occupied by the EAA remains speculative. The best approximation that can be made is a mixed cation-bicarbonate type water whose current analogue is the shallow groundwater beneath STA$1 \mathrm{~W}$ and also Lake Okeechobee itself (Fig. 3).

\section{Changing groundwater and surface-water interactions and effects on chemical transport}

The cycling of Everglades waters back and forth between surface and subsurface domains and associated storage in groundwater is now relatively well understood (Harvey et al. 2005, 2006). However, the effect of groundwater storage-exchange on biogeochemical processes is not as well understood. Over time, that exchange of water between the surface and subsurface is having the effect of replacing what was previously a layer of very highquality, fresh groundwater near the top of the aquifer with contaminated surface water (Fig. 6). Surface-water contaminants such as phosphorus, sulfate, and mercury are increasingly being transported by recharge into peat

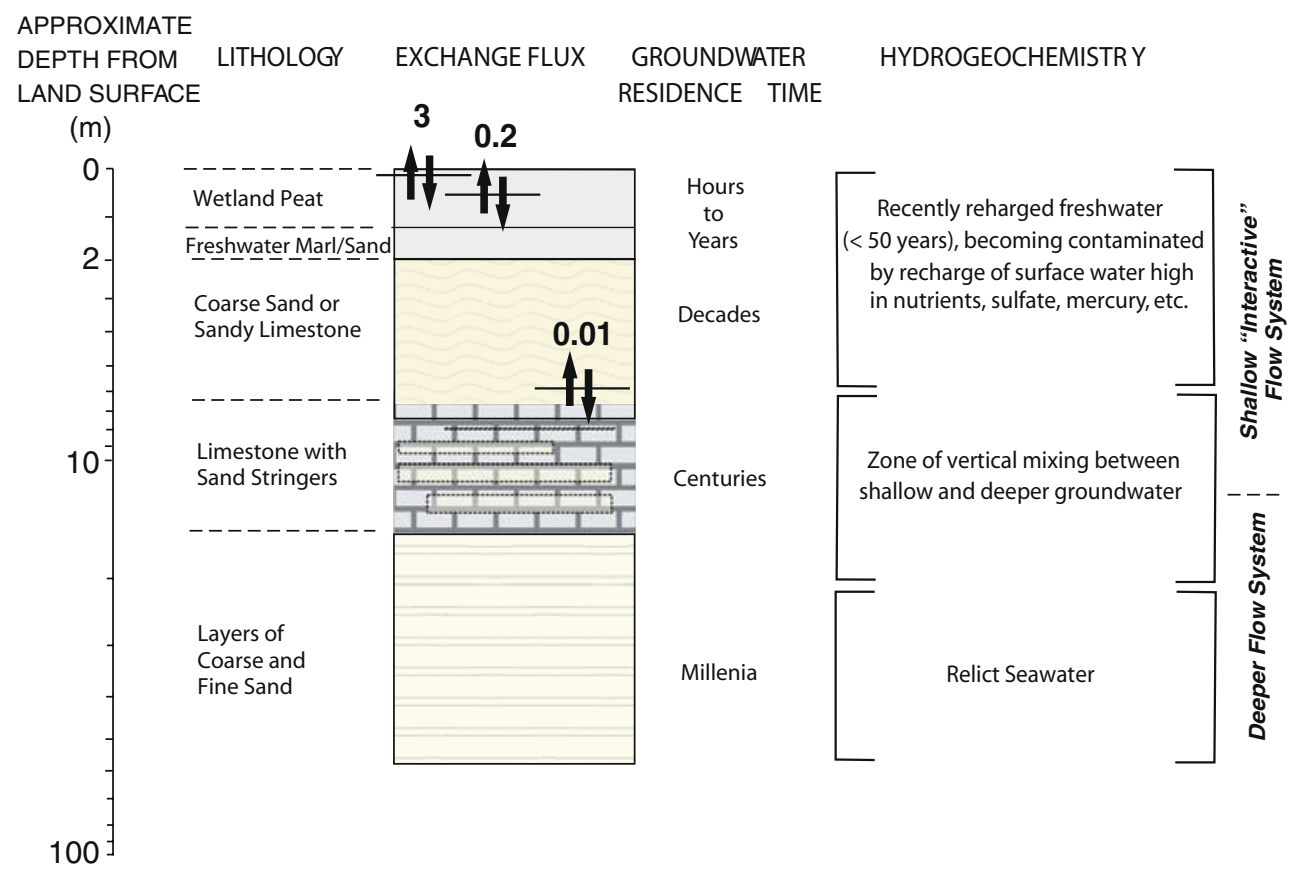

EXPLANATION

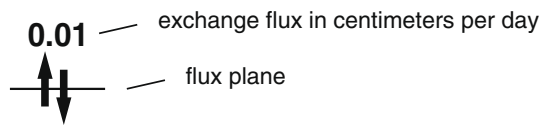

Fig. 6 Summary of lithology, recharge and discharge fluxes between surface water and shallow groundwater in the Biscayne aquifer beneath the central Everglades. The diagram shows the distribution of groundwater residence times in relation to vertical hydrologic fluxes and groundwater hydrogeochemical patterns. The approximate depths of the three flux planes where vertical water fluxes are referenced are approximately at $0.03,0.7$, and $5.3 \mathrm{~m}$. The schematic interpretation was previously published in Harvey et al. (2005) 
porewater and shallow groundwater (Harvey et al. 2002). It is uncertain how long contaminants will be stored in groundwater before being transformed or discharged back to surface water. Both the physical mechanism of contaminant storage in the aquifer and the chemical reactions that occur there may affect contaminant mobility. Contaminants stored in groundwater potentially can return to surface water with discharging groundwater long after restoration management improvements have been implemented. More information is needed about transport and transformation of contaminants in Everglades peat and shallow groundwater, not only for phosphorus, but for a host of surface-water contaminants including sulfate from agricultural drainage, atmospheric-derived mercury, dissolved organic carbon, dissolved salts from discharge of deep groundwater of marine origin with relatively high sulfate and chloride concentrations, and volatile organic carbons of uncertain origin (Krabbenhoft et al. 1998; Bates et al. 2002; Harvey et al. 2002). The potential for these legacies of contamination to affect downstream water quality in the future is significant, and predicting those effects requires a better understanding of how to quantify surface water and groundwater interactions, and how to determine the processes controlling the magnitude of those interactions.

It is important to indicate that water quality concerns are not just for the ecosystem. Municipal water budgets for the lower east coast of Florida indicate that recharge of central Everglades water into the Biscayne aquifer and eastward movement toward domestic well fields is an important source of drinking water. There is still not enough understanding of the source areas, flow paths, and travel times required for Everglades surface water to reach domestic water-supply well fields (Sonenshein 2001; Nemeth and Solo-Gabriele 2001)

\section{Role of changing hydrologic and chemical sources on Everglades ecology}

An increased proportion of surface-water inflows relative to rainfall and increased mineral inputs are some of many processes driving changes in the structure and function of the Everglades. The subtle biological and geochemical dependencies that are being altered by increased mineral inputs have not been investigated to the same extent as nutrient pollution (McCormick et al. 1998), increased variability in water levels and incidences of peat-burning fires, and processes affected by the velocity of sheetflow in the Everglades (Larsen et al. 2007). Here, some effects of increased mineral inputs on biological communities of the Everglades are examined.

\section{Biogeochemical changes}

There is increasing evidence that mineral and phosphorus loading from canals may directly and indirectly affect the bioavailability of many different elements in Everglades peat soils. Measurements of porewater chemistry in the $2-12 \mathrm{~cm}$ depth increment of WCA-1 peat showed higher porewater $\mathrm{pH}$ and higher concentrations of dissolved $\mathrm{P}$ and $\mathrm{N}$ as well as $\mathrm{Mg}^{2+}, \mathrm{Ca}^{2+}, \mathrm{K}^{+}, \mathrm{Cl}^{-}, \mathrm{S}^{2-}$, and sulfate at sampling sites near the edges of WCA-1 (where mixing occurs with canals) compared to more rainfall driven sites in the interior (Susan Newman, SFWMD, personal communication, 2007). Porewater redox levels and dissolved $\mathrm{Fe}$ concentrations were lowest at the sites receiving canal water, apparently due to fertilization of higher metabolic activity and formation of insoluble FeS under low redox conditions.

Organic matter decomposition is a key process controlling both soil formation and nutrient cycling in peatlands. Collection and incubation of equivalent litter of several dominant plant species, sawgrass and cattail, indicated decomposition rates that were up to $30 \%$ faster at wetland sites in WCA-2A at a location that receives canal inflows with high ionic strength, compared with sites in WCA-1 where little canal water intrudes (Newman et al. 2004). Increased mineral loading may be influencing decomposition rates through: (1) increased availability of electron acceptors such as sulfate that are used in anaerobic microbial respiration; (2) increased release of bound phosphorus from peat that fuels higher decomposition rates; and (3) increased activity of minerals such as $\mathrm{Ca}^{2+}$ serving as a co-factors regulating enzyme activity. While not suggesting any specific or well-established causal mechanisms, these findings indicate empirically that intrusion of high ionic strength canal water is promoting faster rates of decomposition.

Sulfate is a significant component of canal water, and has been identified as one of the most widespread contaminants in the Everglades (Bates et al. 2002; Orem 2007). Special importance is attached to sulfate in the Everglades because of its effects on a variety of processes including cycling and bioavailability of $\mathrm{Hg}$, a contaminant that enters the Everglades via atmospheric deposition and is converted to its bioavailable form (methyl-Hg) primarily through microbial pathways (Benoit et al. 2003). Elevated sulfate concentrations also can affect redox potential of Everglades water which can influence specific pathways and rates of decomposition, and can also can affect vegetation patterns due to the inhibitory effects of hydrogen sulfide - an end product of sulfate reductionon plant growth.

\section{Responses of Everglades vegetation}

The Everglades contains many plant species with the most common being sawgrass (Cladium jamaicense), fragrant water lily (Nymphaea odorata), bladderwort (Utricularia spp.), and spikerush (Eleocharis spp.). Few studies in the Everglades have examined spatial patterns of vegetation in relation to water chemistry, although two previous studies of related species of emergent plants in other wetlands found them to be indifferent to surface-water ionic strength (Moyle 1945; Walker and Coupland 1968). In his analysis of aquatic vegetation patterns related to specific conductance, Moyle (1945) noted that "The 
natural separation between hard and soft waters seems to be at a total alkalinity of about $40 \mathrm{mg} / \mathrm{L}, 30 \mathrm{mg} / \mathrm{L}$ being the lower limit of toleration of the more typical hard-water species, and $50 \mathrm{mg} / \mathrm{L}$ the upper limit of toleration of the more characteristic soft-water species" (p. 404). While current information from the Everglades is insufficient to indicate a clear relationship between increasing mineral levels and changes in emergent plant communities, preliminary data by McCormick (SFWMD, unpublished data, 2007) are showing strong relationships between species composition and distance from canals that correlate with concentrations of total dissolved solids in WCA1. However, the observed species distributions and dissolved chemical gradients are correlated with several other environmental changes and, thus, do not provide conclusive proof that increased mineral inputs are the cause of observed vegetation shifts. For example, canal waters had the highest $\mathrm{P}$ concentrations and soil $\mathrm{P}$ concentrations were also highest at sites closest to the canal, and this factor alone can cause pronounced shifts in Everglades vegetation (McCormick et al. 2001). Thus, soil mineral gradients caused by canal-water intrusion are partially confounded by a limiting-nutrient gradient. Water depths also tend to be more variable and greater on average near the canal perimeters of WCA-1. Deeper water depths are another key factor that is known to influence plant species composition in the Everglades.

\section{Response of Everglades periphyton and fauna}

Floating and attached periphyton mats in the Everglades (composed of algae, bacteria, and microfauna) are an important base of the food web providing a food source and habitat for aquatic invertebrates (Williams and Trexler 2006). Periphyton also is important in structuring the ecosystem by reducing phosphorus availability (Noe et al. 2001), blocking light penetration and often dominating primary productivity (Noe et al. 2001), and oxygenating the water column (McCormick and Laing 2003). Periphyton communities are extremely sensitive to changes in water chemistry, which explains their widespread use as indicators of water quality in the Everglades and other aquatic ecosystems.

The interior of WCA-1, which is relatively protected from canal water inputs, contains a characteristic periphyton community dominated by desmid and diatom species indicative of soft-water conditions. Whereas periphyton mats across the high ionic strength portions of the managed Everglades are dominated by calcium-precipitating (calcareous) cyanobacteria and have a high calcium carbonate content, those in WCA-1 are largely organic (noncalcareous) in nature. Paleoecological evidence (Slate and Stevenson 2000) indicates that the community currently found in WCA-1 was probably more widespread across the pre-drainage Everglades when rainfall was a more dominant source of water to this ecosystem. By contrast, calcareous communities historically were more abundant in the marl prairies of the southern Everglades, which support little or no peat accretion due to their short hydroperiods and thus have a water chemistry influenced more strongly by the limestone bedrock.

Surveys conducted by Swift and Nicholas (1987) established periphyton-conductivity relationships across the northern and central Everglades and clearly showed the unique character of the Everglades periphyton community. Their analysis of species-environmental relationships found concentrations of major ions to be the most important factor explaining variation in periphyton taxonomic composition in the central Everglades. Gleason et al. (1975) and McCormick et al. (2000) reported changes in the periphyton community associated with increased intrusion of canal waters along a decreasing gradient of high ionic strength water from the outer boundary to the more rainfall-dominated interior of WCA-1. The major change in the taxonomic composition of the periphyton community across this broader mineral gradient was an increase in the proportion of desmids with decreasing specific conductance (Fig. 7). They concluded that significant alterations in the periphyton community resulted from flows of canal water with high ionic strength into the Everglades. Williams and Trexler (2006) correlated food-web structure with hydrology and nutrient gradients, indicating effects on the distributions of fish and aquatic invertebrates.

\section{Summary and conclusions}

Reconstructions of historic water budgets indicate that direct rainfall was the primary source of water to much of the Everglades prior to start of drainage efforts in the early twentieth century. Seasonal overflows from Lake Okeechobee and runoff from short hydroperiod wetlands and low-lying uplands along the Everglades eastern margin provided most of the additional water to the pre-drainage ecosystem. The mineral content of these other water

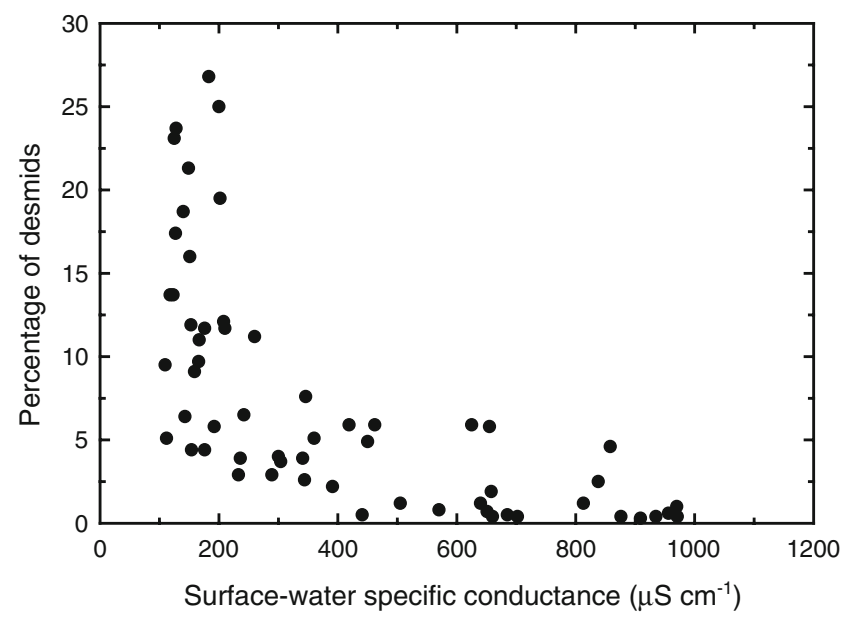

Fig. 7 Changes in desmid dominance within the periphyton community at nine SFWMD monitoring stations across a waterchemistry gradient in the southwest corner of WCA-1, south Florida. Samples were collected during eight sampling trips conducted by the SFWMD between 1996 and 1999 (adapted from McCormick et al. 2000) 
sources was likely higher than that of rainfall but lower than that of surface flows entering the Everglades today. Mineral inputs were low in the pre-drainage Everglades with Lake Okeechobee overflows probably being the primary source with secondary sources from marginal inflows and groundwater discharge. The source of minerals from groundwater has probably increased in the present-day system due to topographic changes resulting from subsidence or removal of the hydraulically resistive peat accumulations within and near canals, and water management practices that increase vertical hydraulic gradients. However, the increased load of minerals entering the Everglades today cannot be explained solely by increases in discharge of groundwater with high ionic strength.

Historic and recent water budgets and environmental tracers were used to assess the relative importance of new sources of minerals, which suggested that canal drainage from the EAA has been the dominant source of increased mineral inputs. Surface-water inflows now account for $33 \%$ of water inputs to the Everglades compared to $18 \%$ in the pre-drainage Everglades. Canal drainage from the EAA, an area that was formerly Everglades and is now farmed, is the largest part of that increase, accounting for more than half of all present-day surface-water inputs. The canal water also has mineral concentrations more than 50 -fold higher than those of rainfall and as much as 10-fold higher than those of surface waters in rainfall-fed areas of the Everglades interior. The ultimate source of water to agricultural canals appears to be predominantly irrigation water pumped from Lake Okeechobee, and secondarily a mixture of direct rainfall onto EAA agricultural fields and discharge of shallow groundwater from beneath the EAA that together flush fertilizer constituents and additives, including $\mathrm{SO}_{4}{ }^{2-}$ and $\mathrm{Ca}^{2+}$ from dissolution of gypsum, a common fertilizer additive in the EAA and elsewhere. Also important is the flushing of natural sulfur in EAA peat soils that have been managed for many decades for agricultural production, and also the chemical conversion and flushing of additional fertilizer additives such as phosphorus and elemental sulfur that are eventually transported by runoff or through shallow groundwater into EAA canals that drain to the Everglades.

Increased mineral inputs to the Everglades are correlated with changes in plant and periphyton species composition and related landscape features such as the cover of slough and sawgrass habitat (Larsen et al. 2007), although specific cause-effect linkages have only begun to be assessed. Recent experiments have demonstrated that fundamental changes occur in periphyton assemblages due to mineral enrichment, with consequences for secondary productivity in the Everglades ecosystem. Alteration of surface-water chemical conditions and its effects on periphyton species assemblages may have cascading effects at higher trophic levels by altering conditions for growth, reproduction and survival of fish and aquatic invertebrates.

Among the major ions and other dissolved constituents, elevated concentrations of phosphorus and sulfate are probably the most significant threat to Everglades ecosystem structure and function. Increased loading of these constituents elicits multiple ecological responses including shifts in macrophyte and periphyton species composition due to higher nutrient availability and production of hydrogen sulfide, which is toxic at high concentrations, as well as increased productivity and decomposition rates, lowered redox potential, increased mercury bioavailability and toxicity. Because of long storage times of contaminated surface waters that are exchanged with shallow groundwater, there are likely to be legacy effects that will prolong the influence of contamination for many decades even after the quality of canal water inputs is improved.

Groundwater's role as a freshwater storage zone that sustains the ecosystem is not yet fully understood. What has become clear in the past several decades is that interactions between groundwater and surface water have increased as a result of water management, resulting in reduced storage of fresh, uncontaminated water in the shallow aquifer located directly beneath the Everglades and also beneath basins such as the EAA that discharge directly into the Everglades. The contamination affecting shallow Everglades groundwater comes both from above and below. Recharge from above is increasingly contaminating shallow groundwater with nutrients, sulfate, mercury, and other contaminants, while the increased vertical hydraulic gradients have contributed to upward transport of salts from the deeper aquifer. Needs for future research and modeling may include: (1) large-scale tracer experiments to investigate fate and transport of contaminants introduced with canal waters, (2) investigation of specific transport and reaction processes for various elements, including information about storage timescales in various compartments such as Everglades soils, vegetation, and groundwater; (3) studies that fill the many data gaps on the ecological effects of mineral enrichment; and (4) improved hydrologic measurements and models to identify strategies to achieve more complete mixing of canal waters at the northernmost possible points of entry to the Everglades, in order to minimize long distance transport of undiluted canal waters into the Everglades.

Hydrologic restoration of the Everglades toward the higher flows characteristic of pre-drainage conditions remains a centerpiece of restoration efforts. However, if greater reliance on canal drainage waters is needed to achieve those hydrologic goals, unintended effects may result that could deliver contaminants such as phosphorus and sulfate farther into the Everglades than ever before. This paper reviewed and synthesized a variety of research projects that collectively suggest that the increasing mineral content of water sources to the Everglades have already altered the structure and function of the Everglades ecosystem, beginning with periphyton communities and food webs, and extending to changes in the dominant species of macrophytes, with cascading effects on fish and invertebrates.

Acknowledgements The investigation was supported by the US Geological Survey's Greater Everglades Priority Ecosystem Sciences Initiative, and by the National Research Program of USGS. We 
thank Lauren McPhillips for assistance with the acquisition and interpretation of chemical data. We are grateful to colleagues Bill Orem, Greg Noe, Laurel Larsen, Ronnie Best, and Aaron Higer of the USGS, Chris McVoy of the South Florida Water Management District, Hydrogeology Journal Guest Editor Andrew Boulton, and two anonymous journal reviewers for comments on the draft, which improved the final manuscript.

\section{References}

Bates AL, Orem WH, Harvey JW, Spiker EC (2002) Tracing sources of sulfur in the Florida Everglades. J Environ Qual 31:287-299

Benoit JM, Gilmour CC, Heyes A, Mason RP, Miller CL (2003) Geochemical and biological controls over methylmercury production and degradation in aquatic ecosystems. In: Chai Y, Braids O (eds) Biogeochemistry of environmentally important trace elements. American Chemical Society, Washington, DC

Chen M, Daourb SH, Lang TA, Diaz OA (2006) Specific conductance and ionic characteristics of farm canals in the Everglades agricultural area. J Environ Qual 35:141-150

Ellery WN, McCarthy TS, Smith ND (2003) Vegetation, hydrology, and sedimentation patterns on the major distributary system of the Okavango fan, Botswana. Wetlands 23:357-375

Fish JE (1988) Hydrogeology, aquifer characteristics, and groundwater flow of the surficial aquifer system, Broward County, Florida. US Geol Surv Water Resour Invest Rep 87-4034

Fish JE, Stewart M (1991) Hydrogeology of the surficial aquifer system, Dade County, Florida. US Geol Surv Water Resour Invest Rep 0-4108

Frazee JM (1982) Geochemical pattern analysis: method of describing the Southeastern Limestone regional aquifer system. In: Beck B (ed) Studies of the hydrogeology of the southeastern United States, Special Publications No. 1. Georgia Southwestern College, Americus, GA, USA, p 1

Glaser PH, Wheeler GA, Gorham E, Wright H (1981) The patterned mires of the Red Lake peatland, northern Minnesota: vegetation, water chemistry, and landforms. J Ecol 69:575-559

Gleason PJ, Stone P (1994) Age, origin, and landscape evolution of the Everglades peatland. In: Davis SM, Ogden JC (eds) Everglades: the ecosystem and its restoration. St Lucie Press, Boca Raton, FL

Gleason PJ, Cohen AD, Brooks HK, Stone PS, Goodwick R, Smith WG, Spackman W Jr (1974) The environmental significance of Holocene sediments from the Everglades and saline tidal plain. In: Gleason PJ (ed) Environments of south Florida: present and past. Miami Geological Society Memoir 2, Miami, FL

Gleason PJ, Stone P, Hallett D, Rosen M (1975) Preliminary report on the effects of agricultural runoff on the periphytic algae of conservation area 1. South Florida Water Management District, West Palm Beach, FL

Gumbricht T, McCarthy J, McCarthy TS (2004) Channels, wetlands and islands in the Okavango Delta, Botswana, and their relation to hydrological and sedimentological processes. Earth Surf Processes Landf 29:15-29

Harvey JW, Krupa SL, Gefvert C, Mooney RH, Choi J, King SA, Giddings JB (2002) Interaction between surface water and ground water and effects on mercury transport in the northcentral Everglades. US Geol Surv Water Resour Invest Rep 024050

Harvey JW, Krupa SL, Krest JM (2004) Ground-water recharge and discharge in the central Everglades. Ground Water 42:1090 1102

Harvey JW, Newlin JT, Krest JM, Choi J, Nemeth EA, Krupa SL (2005) Surface-water and ground-water interactions in the central Everglades, Florida. US Geol Surv Sci Invest Rep 2004-5069

Harvey JW, Newlin JT, Krupa SL (2006) Modeling decadal timescale interactions between surface water and ground water in the central Everglades, Florida, USA. J Hydrol 320:400-420
Howie B (1987) Chemical characteristics of water in the Surficial aquifer system, Broward County, Florida. US Geol Surv Water Resour Invest Rep 86-4330

Jensen JR, Rutchey K, Koch MS, Narumalani S (1995) Inland wetland change detection in the Everglades Water Conservation Area 2A using a time series of normalized remotely sensed data. Photogramm Eng Remote Sens 61:199-209

Krabbenhoft DP, Hurley JP, Olson ML, Cleckner LB (1998) Diel variability of mercury phase and species distributions in the Florida Everglades. Biogeochem 40:311-325

Krupa S, Hill S, Diaz S (2002) Investigation of surface watergroundwater interactions at S-7 pump station, Broward and Palm Beach Counties, Florida. Technical Publication WS-11. South Florida Water Management District, West Palm Beach, FL

Larsen LG, Harvey JW, Crimaldi JP (2007) A delicate balance: ecohydrological feedbacks governing landscape morphology in a lotic peatland. Ecol Monogr 77:591-614. doi:10.1890/06-1267.1

Light SS, Dineen JW (1994) Water control in the Everglades: a historical perspective. In: Davis SM, Ogden JC (eds) Everglades: the ecosystem and its restoration. St Lucie Press, Boca Raton, FL

McCarthy TS (2006) Groundwater in the wetlands of the Okavango Delta, Botswana, and its contribution to the structure and function of the ecosystem. J Hydrol 320:264-282

McCormick PV, Laing J (2003) Effects of increased phosphorus loading on dissolved oxygen in a subtropical wetland, the Florida Everglades. Wetl Ecol Manage 11:199-216

McCormick PV, Shuford RBE III, Backus JG, Kennedy WC (1998) Spatial and seasonal patterns of periphyton biomass and productivity in the northern Everglades, Florida, USA. Hydrobiologia 362:185-208

McCormick PV, Newman S, Payne G, Miao SL, Fontaine TD (2000) Ecological effects of phosphorus enrichment in the Everglades. In: South Florida Water Management District Everglades Consolidated Report, chapt. 3. South Florida Water Management District, West Palm Beach, FL., pp 3-1 and 3-31. https://my.sfwmd.gov/pls/portal/docs/PAGE/PG GRP SFWMD SFER/PORTLET PREVREPORT/ECR2000/ chap03.pdf. Cited 9 October 2008

McCormick PV, Newman S, Miao SL, Reddy KR, Gawlik DE, Fontaine TD III, Marley DJ (2001) Effects of anthropogenic phosphorus inputs on the Everglades. In: Porter JW, Porter KG (eds) The Everglades, Florida Bay, and coral reefs of the Florida Keys: an ecosystem sourcebook. Lewis Publishers, Boca Raton, FL

Miller WL (1978) Effect of bottom sediments on infiltration from the Miami and tributary canals to the Biscayne aquifer, Dade County, Florida. US Geol Surv Water Resour Invest Rep 78-36

Miller WL (1988) Description and evaluation of the effects of urban and agricultural development on the Surficial aquifer system, Palm Beach County, Florida. US Geol Surv Water Resour Invest Rep 88-4056

Moyle JB (1945) Some chemical factors influencing the distribution of aquatic plants in Minnesota. Am Midl Nat 34:402-420

Nemeth MS, Solo-Gabriele HM (2001) Evaluation of the use of reach transmissivity to quantify exchange between groundwater and surface water. J Hydrol 274:145-159

Newman S, Penton CR, Jacoby M, Gray I (2004) Integrating carbon and nitrogen with organic phosphorus turnover during litter decomposition in the Everglades. In: American Society of Limnology and Oceanography Annual Meeting, June 2004, Savannah, GA

Noe GB, Childers DL, Jones RD (2001) Phosphorus biogeochemistry and the impact of phosphorus enrichment: Why is the Everglades so unique? Ecosystems 4:603-624

Orem W (2007) Sulfur contamination in the Florida Everglades: initial examination of mitigation strategies: US Geol Surv Open-File Rep 2007-1374

Parker GG, Ferguson GE, Love SK et al (1955) Water Resources of Southeastern Florida, with special reference to the geology and ground water of the Miami area: US Geol Surv Water Suppl Pap 1255

Price RM, Swart PK (2006) Geochemical indicators of groundwater recharge in the surficial aquifer system, Everglades National 
Park, Florida, USA. Geological Society of America Special Paper 404. GSA, Boulder, CO. doi: 10.1130/2006.2404(21)

Price RM, Top Z, Happell JD, Swart PK (2003) Use of tritium and helium to define groundwater flow conditions in Everglades National Park. Water Resour Res 39(9), 1267. doi:10.1029/ 2002WR001929

Reese RS, Cunningham KJ (2000) Hydrogeology of the Gray limestone aquifer in southern Florida. US Geol Surv Water Resour Invest Rep 99-4213

Renken RA, Dixon J, Koehmstedt J, Ishman S, Lietz AC, Marella RL, Telis P, Rogers J, Memberg S (2005) Impact of anthropogenic development of coastal ground-water hydrology in southeastern Florida, 1900-2000: US Geol Surv Circ 1275

Rutchey K, Vilchek L (1999) Air photointerpretation and satellite imagery analysis techniques for mapping cattail coverage in a northern Everglades impoundment. Photogram Eng Remote Sens 65(2):185-191

San Jose JJ, Meirelles ML, Bracho R, Nikonovan N (2001) A comparative analysis of the flooding and fire effects on the energy exchange in a wetland community (Morichal) or the Orinoco Llanos. J Hydrol 242:228-254

Schueneman TJ (2001) Characterization of sulfur sources in the EAA. Soil Crop Sci Soc Florida 60:49-52

Science Coordination Team (2003) The role of flow in the Everglades ridge and slough landscape. http://www.sfrestore. org/sct/docs/. Cited May 2008

Siegel DI, Glaser PH (1987) Groundwater flow in a bog-fen complex, Lost River Peatland, northern Minnesota. J Ecol 75:743-754

Slate JE, Stevenson RJ (2000) Recent and abrupt changes in the Florida Everglades indicated by siliceous microfossils. Wetlands 20:346-356

Sonenshein RS (2001) Methods to quantify seepage beneath Levee 30, Miami-Dade County, Florida: US Geol Surv Water Resour Invest Rep 01-4074

South Florida Water Management District (SFWMD) (1999) A primer to the South Florida Water Management Model (version 3.5). SFWMD, West Palm Beach, FL. https://my.sfwmd.gov/ portal/page? pageid $=1314,2556275,13142554821: 131425$ $54854 \&$ dad $=$ portal $\&$ schema $=$ PORTAL. $\overline{\text { Cited }} 9$ April $2 \overline{00} 4$
South Florida Water Management District (SFWMD) (2003) Central and Southern Florida Project Comprehensive Review Study. SFWMD, West Palm Beach, FL. http://my.sfwmd.gov/ sfwmd/hesm/hpm/index.html. Cited 9 April 2004

South Florida Water Management District (SFWMD) (2006) Natural System Model (NSM) Version 4.5. SFWMD, West Palm Beach, FL. https://my.sfwmd.gov/pls/portal/docs/page/pg_grp_sfwmd_hesm/ portlet_nsm/portlet_subtab_nsm_documents/tab1354050/nsm 45 . pdf. Cited 20 December $20 \overline{0} 6$

South Florida Water Management District (SFWMD) (2008) DBHydro Browser Menu. SFWMD, West Palm Beach, FL. http://my.sfwmd.gov/dbhydroplsql/show_dbkey_info.main_ menu. Cited 23 April 2008

Stober J, Schiedt D, Jones R, Thornton K, Ambrose R, France D (1998) South Florida ecosystem assessment: monitoring for adaptive management: implications for ecosystem restoration: Final Technical Report-Phase I, EPA-904-R-98-002, USEPA, Washington, DC

Swift DR, Nicholas RB (1987) Periphyton and water quality relationships in the Everglades water conservation areas 1978-1982. Technical Publication 87-2. SFWMD, West Palm Beach, FL

US Army Corps of Engineers (1999) C\&SF comprehensive review study: final integrated feasibility report and programmatic impact statement (PEIS). US Army Corps of Engineers, Washington, DC. http://www.evergladesplan.org/pub/restudy_eis.aspx. 20 December 2006

Walker BH, Coupland RT (1968) An analysis of vegetation: environmental relationships in Saskatchewan sloughs. Can J Botan 46:509-522

Williams AJ, Trexler JC (2006) A preliminary analysis of the correlation of food-web characteristics with hydrology and nutrient gradients in the southern Everglades. Hydrobiol 569:493-504

Winkler MG, Sanford PR, Kaplan SW (2001) Hydrology, vegetation and climate change in the southern Everglades during the Holocene. Bull Am Paleontol 361:57-100

Zielinski RA, Simmons KR, Orem WH (2000) Use of 234U and $238 \mathrm{U}$ isotopes to identify fertilizer-derived uranium in the Florida Everglades. Appl Geochem 15:369-383 